\title{
Fish-food interaction network around cage fish farming in a neotropical reservoir
}

\author{
Rede de interaçóes peixe-alimento ao redor de piscicultura com tanque-rede em um \\ reservatório neotropical
}

Heleno Brandão ${ }^{1 *}$ (D), Denise Lange ${ }^{1}$ (D), Daniel Rodrigues Blanco' ${ }^{1}$ (D), Igor Paiva Ramos² (D), Jamile Queiroz de Sousa ${ }^{3}$ (D), André Batista Nobile ${ }^{3}$ (D) and Edmir Daniel Carvalho ${ }^{3 \dagger}$

\begin{abstract}
${ }^{1}$ Universidade Tecnológica Federal do Paraná - UTFPR, Campus Santa Helena, Prolongamento da Rua Cerejeira, Bairro São Luiz, CEP 85892-000, Santa Helena, PR, Brasil

${ }^{2}$ Departamento de Biologia e Zootecnia, Faculdade de Engenharia de Ilha Solteira, Universidade Estadual Paulista - UNESP, Rua Monção, 226, Zona Norte, CEP 15385-000, Ilha Solteira, SP, Brasil

${ }^{3}$ Programa de Pós-graduação em Ciências Biológicas, Zoologia, Instituto de Biociências, Universidade Estadual Paulista - UNESP, Rua Prof. Dr. Antônio Celso Wagner Zanin, 250, Distrito de Rubiāo Junior, CEP 18618-689, Botucatu, SP, Brasil

${ }^{\dagger}$ In memorian

*e-mail: helenob@utfpr.edu.br
\end{abstract}

Cite as: Brandão, H. et al. Fish-food interaction network around cage fish farming in a neotropical reservoir. Acta Limnologica Brasiliensia, 2021, vol. 33, e18.

\begin{abstract}
Aim: Investigating whether wild fish accept residual ration from cage fish farming to the point of changing their diet and the fish-food interaction network. Methods: The diet of fish species, Astyanax lacustris, Iheringichthys labrosus, Leporinus amblyrhynchus, Schizodon nasutus and Steindachnerina insculpta, bred in Chavantes Reservoir, Upper Paraná basin, was evaluated. Samples were collected on a monthly basis - from March 2008 to February 2009 - around the cage fish farming (NC) and in a reference site (RS) free from the influence of the fish farming activity. Results were analyzed through graphs and metrics of complex network analysis, and Permutational analysis of variance. Results: The total number of 641 individuals belonging to all five fish species were collected, 292 in NC and 349 in RS. The total amount of food items consumed by them comprised 24 items in $\mathrm{NC}$ and 22 items in RS. The fish-food interaction network has shown nested pattern in the two evaluated areas, which evidenced the generalist structure of this interaction. Connectance values and mean degree of interaction networks were low. Detritus was the most representative item consumed in both sampling sites. Three of the five evaluated species (A. lacustris, S. nasutus and I. labrosus) had residual ration in their diet. Residual ration was the fourth most consumed item in NC. It was also the most representative food item for $A$. lacustris and $S$. nasutus. Conclusions: Results have shown that cage fish farming activity can influence trophic interactions in aquatic systems, as well as evidenced the ability of $S$. nasutus, L. labrosus and A. lacustris to take advantage of new food items in their environment.
\end{abstract}

Keywords: aquaculture; Chavantes Reservoir; ecological interaction; teleost.

Resumo: Objetivo: Nós verificamos se peixes selvagens se alimentam de ração residual proveniente de piscicultura em tanques-rede, alterando a dieta e a rede de interação peixe-alimento. Métodos: Foram avaliadas as dietas de Astyanax lacustris, Iheringichthys labrosus, Leporinus amblyrhynchus, Schizodon 
nasutus e Steindachnerina insculpta do Reservatório Chavantes, Bacia do Alto Paraná. Os peixes foram coletados mensalmente de março de 2008 a fevereiro de 2009 ao redor da área de piscicultura (net cage - NC) e em uma área de referência (reference site - RS), sem a influência das atividades de piscicultura. Nós verificamos os resultados usando gráficos e métricas da análise de redes complexas e análise de variância permutacional. Resultados: Foram coletados 641 indivíduos das cinco espécies de peixes, 292 na área NC e 349 na RS. No total 24 itens alimentares foram consumidos pelos peixes em NC e 22 em RS. A rede de interação peixe-alimento apresentou padrão aninhado nas duas áreas avaliadas, demonstrando a estrutura generalista desta interaçáo. Os valores de conectância e grau médio da rede de interação foram baixos. Detrito foi o item mais consumido nas duas áreas avaliadas. Três das cinco espécies avaliadas (A. lacustris, $S$. nasutus e I. labrosus) tiveram ração residual em suas dietas. Ração foi o quarto item mais consumido na área NC, sendo o mais frequente em indivíduos de $A$. lacustris e $S$. nasutus. Conclusóes: Os nossos resultados mostram que a atividade de piscicultura usando tanques-rede pode influenciar as interaçóes tróficas dos sistemas aquáticos, bem como, demonstram a habilidade de $S$. nasutus, L. labrosus e A. lacustris em consumirem o novo item alimentar inserido no ambiente.

Palavras-chave: piscicultura; reservatório Chavantes; interações ecológicas; teleósteos.

\section{Introduction}

Aquaculture is one of most relevant zootechnical activities in constant development worldwide. It happens due to the demand for aquatic products for human consumption (Vélez et al., 2017). Brazil has 139 registered aquaculture parks distributed in 1,556 different sites that, all together, cover 941,38 hectares (Lima et al., 2018). Although aquaculture is increasing in the Brazilian territory, this activity faces several environmental regulation challenges, such as conflicts of interest and questionable sustainability (Nobile et al., 2020).

Negative effects caused by cage fish farming systems have already been investigated in marine (Bartozek et al., 2014; Hedberg et al., 2015; Price et al., 2015; Tomassetti et al., 2016; Barrett et al., 2019) and freshwater ecosystems (Hakanson, 2005; Carvalho et al., 2012; Demétrio et al., 2012; Ramos et al., 2013; Kliemann et al., 2018; Nobile et al., 2018, 2020) in several regions all around the globe. This activity leads to changes in natural environments, wild animal populations and landscape. Changes in landscape comprise the insertion of physical structures (cages) for fish breeding in captivity (Ramos et al., 2013; Brandão et al., 2014; Zaniboni-Filho et al., 2018). Moreover, high fish-stocking densities within these farms accumulate biomass amounts in open systems far beyond the natural levels and can provide considerable amount of trophic food for wild animals living out of cages (Ramos et al., 2013; Brandão et al., 2014; Barrett et al., 2019). Changes in benthic macroinvertebrate communities (Cyrino et al., 2010; Nabirye et al., 2016) is another negative effect of cage fish farming systems. Thus, researchers have been trying to get to consensus between sustainable fish production and damage to aquatic ecosystems, based on procedures such as delimiting suitable locations for aquaculture sites, using mathematical modeling to determine the carrying capacity of the environment (David et al., 2015) and, more recently, Integrated Multitrophic Aquaculture - IMTA (see Ning et al., 2016; Montalto et al., 2017).

The aim of the current study was to analyze aquaculture-related impacts on wild fish populations. The fish-food interaction network structure in cage fish farming was investigated based on food items consumed by five wild fish species, which were compared to the diet of fish living in environment free from fish farm systems (herein called reference site). The main hypothesis was that the investigated fish would include residual ration from fish farming in the local fish-food interaction system, thus turning it into one of the main consumed food items and changing the food web of the aquatic community living in this environment.

\section{Material and Methods}

\subsection{Study site}

The study was carried out in private cage fish farming in Chavantes Reservoir, Paranapanema River, Paraná State, Brazil. The reservoir is located 480 meters above sea level, as well as presents maximum depth ranging from $70 \mathrm{~m}$ to $90 \mathrm{~m}$, total volume of $9,410 \times 10^{6} \mathrm{~m}^{3}$ and total area of $400 \mathrm{~km}^{2}$ (Duke Energy, 2008).

Two sites were selected for the current study: one around cage fish farming (NC) (237'29.03” S $\left.49^{\circ} 37^{\prime} 38.97^{\prime \prime} \mathrm{W}\right)$, and another one located $3 \mathrm{~km}$ upstream the fish farming, in order to avoid any kind of influence from it (Reference Site - RS) $\left(23^{\circ} 7^{\prime} 55,58^{\prime \prime} \mathrm{S} 49^{\circ} 36^{\prime} 14,03^{\prime \prime} \mathrm{W}\right)$ (Figure 1). The 


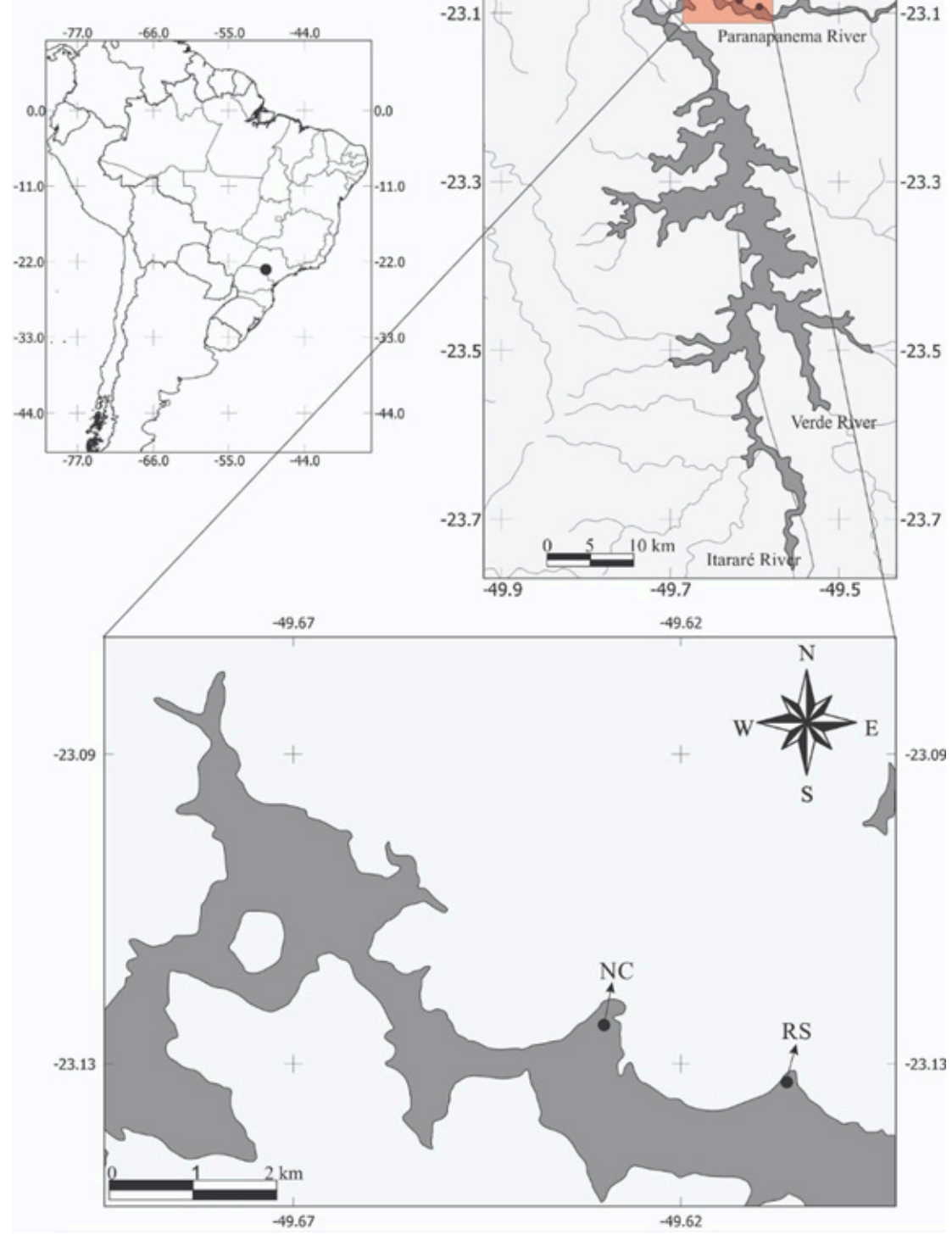

Figure 1. Location of Chavantes Reservoir in Paranapanema River, Brazil. Sites: fish farming with net cage and reference site.

two selected sites present rocks, mesophilic forest fragments and coastline with aquatic macrophytes.

\subsection{Fish capture}

Fish were captured with gill nets at different mesh sizes $(3 \mathrm{~cm}$ to $14 \mathrm{~cm}$ between nonadjacent knots; height ranging from $1.44 \mathrm{~m}$ to $2.20 \mathrm{~m}$ ), from 5:00 p.m. to 7:00 a.m., on a monthly basis, from March 2008 to February 2009 (IBAMA/ICMBio license: 15549-1). In total, 27 fish species were collected in these sites during this period (see Nobile, 2010); however, only 5 fish species were selected for the current study, based on the following features: (i) presence on both sites (NC and RS) and at the same capture periods, (ii) abundance of individuals to enable comparison between sites, and (iii) recorded incidence in Paraná basin (Buckup et al., 2007; Graça \& Pavanelli, 2007; Brandão et al., 2009). Astyanax lacustris (Lütken, 1875), Iheringichthys labrosus (Lütken, 1874); Leporinus amblyrhynchus Garavello and Britski, 1987; Schizodon nasutus Kner, 1858; and Steindachnerina insculpta Fernández-Yépez, 1948 were the five selected species. Dietary analysis of other collected species had already been published in studies such as Brandão et al. $(2012,2013,2014)$.

Vouchers of the evaluated fish species (A. lacustris LBP 4794; I. labrosus LBP 4811, L. amblyrhynchus LBP 4581, S. nasutus LBP 4821, S. insculpta LBP 4823) were deposited at Laboratório de 
Biologia e Genética de Peixes (LBP), Instituto de Biociências of Universidade Estadual Paulista (UNESP), Botucatu County, São Paulo State, Brazil.

\subsection{Analysis of stomach contents}

Stomach contents were examined in stereomicroscope. Food items were identified based on the following identification keys: Bicudo \& Bicudo (1970), for algae; Mugnai et al. (2010), for invertebrates; and Ota et al. (2018), for fish. These items were quantified based on the gravimetric method by Hyslop (1980) by using the mass of each item measured in precision analytical balance $(0.0001 \mathrm{~g})$. Whenever this procedure could not be performed, as in the case of small items, a value (\%) was attributed to the total mass of stomach contents.

Properties of the interaction network established between individuals belonging to all five investigated species and food items found in their digestive system were analyzed based on two adjacency matrices built (one for each site) with, and without, these interactions. Only individuals presenting food items in their digestive system were taken into consideration in this analysis, namely: L. amblyrhynchus (RS $=07 ; \mathrm{NC}=07$ ), $S$. nasutus $(\mathrm{RS}=39 ; \mathrm{NC}=13)$, A . lacustris $(\mathrm{RS}=126$; $\mathrm{NC}=77)$, I. labrosus $(\mathrm{RS}=31 ; \mathrm{NC}=83)$, and S. insculpta (RS = 49; NC = 10).

\subsection{Data analysis}

Complex network analysis was applied to test the hypothesis that the residual ration escaping the cages can change the trophic network of the ichthyofauna. Two fish-food interaction networks were built (one for each site) based on two matrices presenting, or not, food items consumed by fish. Metrics used to analyze the interaction network structures were described as follows: network connectance, mean value recorded for food items consumed by fish (mean degree sensu Dormann et al., 2009); the principal-peripheral core (Lange et al., 2013) of food items in the networks. The existence of nestedness (NODF - Nestedness metric based on Overlap and Decreasing Fill, Almeida-Neto et al., 2008) in the networks were also investigated in Aninhado software, version 3.0 (Guimarães Júnior \& Guimarães, 2006). The significance of NODF index was estimated through Monte Carlo procedure, based on 1,000 randomizations to the null model (Ce), which kept the total value of fixed lines during randomizations (Guimarães Júnior \& Guimarães, 2006). NODF index ranges from 0 (no nestedness) to 100 (perfect nestedness) and measures to which extent few fish interactions form a subset of fish interactions accountable for the establishment of more interactions (AlmeidaNeto et al., 2008). Thus, bipartite networks are nested when species presenting fewer interactions are preferentially associated with a subset of species that interact with the most connected ones (Bascompte et al. 2003). Connectance of networks $(\mathrm{C})$ is the proportion at which possible interactions are performed: $C=L /\left(I^{*}\right)$, wherein $\mathrm{L}=$ performed interactions; $\mathrm{I}=$ number of fish individuals; $\mathrm{J}=$ number of food items (Jordano, 1987). Maximum connectance value is 1 , when all species are connected to food items. In order to assess the composition of food items along the principal-peripheral core of networks, consumption core was calculated based on $\left(\mathrm{G}_{\mathrm{C}}\right): \mathrm{G}_{\mathrm{C}}=\left(\mathrm{k}_{\mathrm{i}}\right.$ $\left.\mathrm{k}_{\text {mean }}\right) / \mathrm{z}$, wherein $\mathrm{k}_{\mathrm{i}}$ is the number of individual food item-fish interactions in each network, $\mathrm{k}_{\text {mean }}$ is the number of all food item-fish interactions in each network, and $\mathrm{z}$ is the standard deviation (SD) of the number of food item-fish interactions in each network. $G_{C}>1$ corresponds to food items presenting higher interaction rates than the other items; therefore, these items belong to the principal core. $\mathrm{G}_{\mathrm{C}}<1$ corresponds to food items presenting lower interaction rates than the other items; therefore, these items belong to the peripheral core (Dáttilo et al., 2013). Pajek 5.0 software package (Batagelj \& Mrvar, 1998) was used to plot the bipartite graphs.

One-way PERMANOVA analysis was performed based on Bray-Curtis distance to test differences in diet composition between sites (Anderson, 2001). Subsequently, the Percent Similarity method (SIMPER overall pool) was applied, also based on Bray-Curtis distance (Clarke, 1993), to investigate the food items mostly contributing to these differences. One-way PERMANOVA and SIMPER overall pool analyses were performed in the Primer + Permanova 6.0 software. P value $<0.05$ was adopted as significance threshold in all statistical analyses.

\section{Results}

The total number of 641 individuals belonging to five fish species were collected: 292 in NC and 349 in RS. The total amount of food items consumed by the investigated fish comprised 24 items in NC and 22 items in RS (Figure 2). Only $\mathrm{NC}$ had exclusive items, spider and residual ration (herein considered as particles). Each fish consumed 


\section{Referente Site}

\section{Fish Farm}
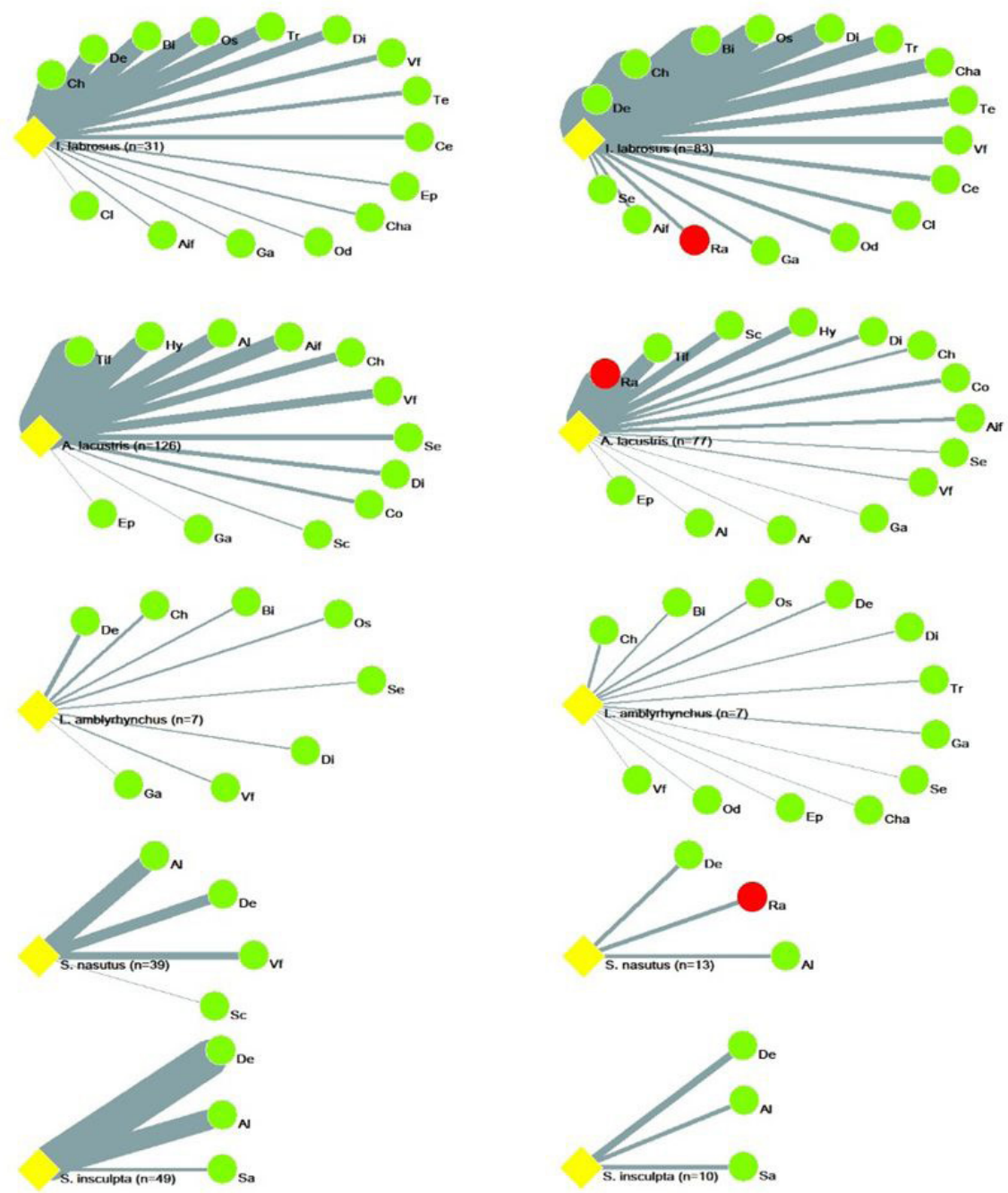

Figure 2. Representation of total interaction network recorded for all five fish species in the fish farming (NC) and reference sites (RS). Edge thickness represents the number of interactions among individuals belonging to the investigated fish species (yellow diamonds), food item (green circles) and residual ration (red circles). For a list with the codes used in the networks, please see Table 3.

2.01 food items in RS and 2.88 in NC, presenting the average degree of fish in network. The low mean degree value reflected the connectance of food item-fish interaction networks, which only resulted in $9.16 \%$ possible interactions established in $\mathrm{RS}$ and in $12.03 \%$, in NC. These results are indicative that the investigated fish species were generalists, since they consumed different food items.

The two investigated networks presented low, although significant, nested pattern $(\mathrm{RS}=13.91$; $\mathrm{p}<0.01$, and $\mathrm{NC}=13.51 ; \mathrm{p}<0.01)$, and showed that individuals who ate a small variety of food items consumed the same items as those consumed by individuals who ate a larger variety of them. This outcome has indicated that the most specialized individuals in the network were actually a subgroup of more generalist individuals (Figure 2).

Three fish species consumed residual ration, namely: S. nasutus, I. labrosus and A. lacustris (Figure 2). They presented differences in diet composition between sampling sites ( $S$. nasutus; $\mathrm{F}_{[1]}=3.730$; I. labrosus, $\mathrm{F}_{[1]}=6.535$; and A. lacustris, $\mathrm{F}_{[1]}=32.842$; all species $\mathrm{p}<0.001$; Table 1 ). Astyanax lacustris consumed residual ration almost exclusively (87.3\%) (Table 1 and Figure 2). Leporinus amblyrhynchus $\left(\mathrm{F}_{[1]}=1.140, \mathrm{p}=0.338\right)$ and $S$. insculpta $\left(\mathrm{F}_{[1]}=8.578, \mathrm{p}=0.985\right)$ did not present differences in diet composition between 
Table 1. Food item mass percentage consumed by all five fish species caught around the fish farming (NC) and in the reference site (RS) in Chavantes Reservoir, Paraná State, Brazil. The highest values were highlighted in bold. Dashes (-) mean absence of consumption or too low consumption values.

\begin{tabular}{|c|c|c|c|c|c|c|c|c|c|c|}
\hline \multirow{2}{*}{ Food items } & \multicolumn{2}{|c|}{ S. insculpta } & \multicolumn{2}{|c|}{ I. labrosus } & \multicolumn{2}{|c|}{ A. lacustris } & \multicolumn{2}{|c|}{ S. nasutus } & \multicolumn{2}{|c|}{ L. amblyrhynchus } \\
\hline & NC & RS & NC & RS & NC & RS & NC & RS & NC & RS \\
\hline Number of individuals & 11 & 51 & 121 & 50 & 127 & 146 & 17 & 58 & 16 & 44 \\
\hline Length class ranges $(\mathrm{cm})$ & $11-15$ & $9.6-14.5$ & $10.5-21$ & $12-20.5$ & $6.2-14.5$ & $6-11.5$ & $10.6-26$ & $10.5-29$ & $10.3-16.6$ & $9.4-14.2$ \\
\hline Algae & 6.4 & 4.3 & - & - & 0.6 & 10.5 & 6.8 & 76.6 & - & - \\
\hline Aquatic Insect fragments & - & - & 0.6 & 1.0 & 0.5 & 5.5 & - & - & - & - \\
\hline Araneae & - & - & - & - & 0.003 & - & - & - & - & - \\
\hline Bivalvia & - & - & 5.1 & 39.7 & - & - & - & - & 1.5 & 14.4 \\
\hline Calboridae & - & - & 0.3 & 0.3 & - & - & - & - & 0.1 & - \\
\hline Ceratopogonidae & - & - & 0.03 & 0.5 & & - & - & - & - & - \\
\hline Chironomidae & - & - & 7.9 & 8.0 & 0.1 & 0.5 & - & - & 11.4 & 16.2 \\
\hline Cladocera & - & - & 0.1 & 0.005 & - & - & - & - & - & - \\
\hline Coleoptera & - & - & - & - & 0.6 & 3.3 & - & - & - & - \\
\hline Cyanophycea & - & - & - & - & - & - & - & - & - & - \\
\hline Detritus & 47.1 & 93.1 & 74.2 & 39.0 & - & - & 75.9 & 5.2 & 2.2 & 62.2 \\
\hline Diptera & - & - & 0.3 & 1.2 & 0.1 & 0.3 & - & - & 0.3 & 1.3 \\
\hline Ephemeroptera & - & - & - & 0.1 & 0.004 & 0.01 & - & - & 0.7 & - \\
\hline Gastropoda & - & - & 0.1 & 0.9 & 0.008 & 0.1 & - & - & 22.8 & 0.8 \\
\hline Hemiptera & - & - & - & - & - & - & - & - & - & - \\
\hline Hymenoptera & - & - & - & - & 3.3 & 29.3 & - & - & - & - \\
\hline Insect fragments & - & - & - & - & - & - & - & - & - & - \\
\hline Odonata & - & - & 0.7 & 0.9 & - & - & - & - & 1.7 & - \\
\hline Ostracoda & - & - & 0.6 & 6.0 & - & - & - & - & 0.1 & 0.6 \\
\hline Residual ration & - & - & 6.0 & - & 87.3 & - & 17.3 & - & - & - \\
\hline Sand & 46.5 & 2.6 & - & - & - & - & - & - & - & - \\
\hline Scales & - & - & - & - & 4.4 & 0.02 & - & 0.2 & - & - \\
\hline Seed & - & - & 0.3 & - & 1.5 & 21.1 & - & - & 0.03 & 3.4 \\
\hline Tecameba & - & - & 0.1 & 0.005 & - & - & - & - & - & - \\
\hline $\begin{array}{l}\text { Terrestrial insect } \\
\text { fragments }\end{array}$ & - & - & - & - & 1.4 & 24.4 & - & - & - & - \\
\hline Trichoptera & - & - & 0.5 & 2.2 & - & - & - & - & 0.5 & - \\
\hline Vegetable fragments & - & - & 3.3 & 0.1 & 0.2 & 4.9 & - & 17.9 & 58.6 & 1.1 \\
\hline Total of items & 3 & 3 & 16 & 15 & 14 & 12 & 3 & 4 & 12 & 8 \\
\hline
\end{tabular}

sampling sites. With respect to habits, I. labrosus, L. amblyrhynchus and A. lacustris consumed food from different origins, which indicated omnivorous diet, whereas $S$. insculpta and $S$. nasutus preferentially consumed detritus, which indicated detritivore diet (Tables 1, 2 and 3, and Figure 2).

Items mostly consumed in the net cage site comprised detritus, Chironomidae, Bivalvia and residual ration $(94,75,62$ and 60 records, respectively (Table 3). Other consumed items encompassed seeds, Coleoptera, sand, Cladocera (six occurrences, each), Ephemeroptera (two occurrences), and spider (one occurrence). Items mostly consumed in the reference site comprised detritus, algae and terrestrial insect fragments (95, 72 and 71, respectively; Table 3). Other items encompassed Ceratopagonidae, Tecameba, Coleoptera and
Gastropoda. The incidence of other items can be checked in the Table 3 and in Figure 2.

\section{Discussion}

Results have shown that three of the five evaluated species (A. lacustris, S. nasutus, and I. labrosus) consumed residual ration deriving from cage fish farming activities and presented diet composition different from fish populations living under natural environmental conditions. The other evaluated fish species, L. amblyrhynchus, fed on gastropods and Chironomidae in RS - which can be associated with local organic enrichment resulting from the entry of organic matter deriving from fish farming (Kliemann et al., 2018), as well as with increased number of pollution-tolerant organisms, such as Chironomus sp. (Nabirye et al., 2016). Leporinus amblyrhynchus has been evaluated 
Table 2. Similarity Analysis (SIMPER) applied to food items consumed by three species that fed on residual ration between sampling sites: fish farming (NC) and reference site (RS) in Chavantes Reservoir, Brazil.

\begin{tabular}{|c|c|c|c|c|c|c|}
\hline \multicolumn{7}{|l|}{ A. lacustris } \\
\hline \multicolumn{7}{|l|}{$A D=93.18$} \\
\hline Food item & $\mathrm{MA}-\mathrm{NC}$ & MA - RS & $A / D$ & DISS/SD & C \% & $\mathrm{CC}$ \\
\hline Residual ration & 0.23 & 0.0 & 35.91 & 1.15 & 38.54 & 38.54 \\
\hline Terrestrial insect fragments & 0.02 & 0.07 & 17.58 & 0.89 & 18.86 & 57.4 \\
\hline Hymenoptera & 0.02 & 0.04 & 11.19 & 0.52 & 12.01 & 69.41 \\
\hline Algae & 0 & 0.03 & 6.07 & 0.38 & 6.52 & 75.92 \\
\hline Aquatic insect fragments & 0.01 & 0.02 & 5.72 & 0.42 & 6.13 & 82.06 \\
\hline Seeds & 0.01 & 0.02 & 4.07 & 0.28 & 4.36 & 86.42 \\
\hline Coleoptera & 0.01 & 0.01 & 3.2 & 0.3 & 3.44 & 89.86 \\
\hline Scales & 0.02 & 0.0 & 3.18 & 0.33 & 3.41 & 93.27 \\
\hline I. labrosus & $M A-N C$ & MA - RS & $\mathrm{A} / \mathrm{D}$ & DISS/SD & $\mathrm{C} \%$ & $\mathrm{CC}$ \\
\hline \multicolumn{7}{|l|}{$A D=59.69$} \\
\hline \multicolumn{7}{|l|}{ Food item } \\
\hline Detritus & 0.23 & 0.12 & 23.18 & 1.37 & 38.83 & 38.83 \\
\hline Bivalvia & 0.05 & 0.07 & 8.73 & 0.99 & 14.62 & 53.45 \\
\hline Chironomidae & 0.07 & 0.05 & 7.59 & 1.05 & 12.71 & 66.16 \\
\hline Ostracoda & 0.01 & 0.04 & 5.13 & 0.76 & 8.59 & 74.75 \\
\hline Trichoptera & 0.01 & 0.02 & 3.84 & 0.89 & 6.43 & 81.18 \\
\hline Vegetable fragments & 0.02 & 0.01 & 2.2 & 0.43 & 3.68 & 84.86 \\
\hline Diptera & 0.01 & 0.01 & 2.04 & 0.91 & 3.42 & 88.28 \\
\hline Residual ration & 0.02 & 0.0 & 1.63 & 0.21 & 2.73 & 91.01 \\
\hline \multicolumn{7}{|l|}{ S. nasutus } \\
\hline$A D=85.55$ & $M A-N C$ & MA - RS & $\mathrm{A} / \mathrm{D}$ & DISS/SD & $\mathrm{C} \%$ & $\mathrm{CC}$ \\
\hline \multicolumn{7}{|l|}{ Food item } \\
\hline Algae & 0.07 & 0.32 & 30.38 & 1.04 & 35.51 & 35.51 \\
\hline Detritus & 0.2 & 0.08 & 24.44 & 0.89 & 28.56 & 64.07 \\
\hline Residual ration & 0.13 & 0.01 & 18.27 & 0.82 & 21.35 & 85.42 \\
\hline Vegetable fragments & 0.0 & 0.1 & 11.58 & 0.5 & 13.54 & 98.96 \\
\hline
\end{tabular}

Average dissimilarity AD; Contribution \% (C); Cumulative contribution \% (CC); Mean abundance in fish farming (MA - NC); Mean abundance in reference site (MA - RS); Average dissimilarity A/D and Standard Deviation of dissimilarity DISS/SD.

Table 3. Number of food item-fish interactions and classification of food items into principal-peripheral core $\left(\mathrm{G}_{\mathrm{C}}\right.$ index) for networks in Figure 2.

\begin{tabular}{|c|c|c|c|c|c|}
\hline \multirow[t]{2}{*}{ Code } & \multirow[t]{2}{*}{ Food items } & \multicolumn{2}{|c|}{ Number of Interactions } & \multicolumn{2}{|c|}{$\begin{array}{c}\text { Classification of } \\
\text { principal-peripheral core }\end{array}$} \\
\hline & & RS & NC & RS & NC \\
\hline $\mathrm{De}$ & Detritus & 95 & 94 & Main & Main \\
\hline Al & Algae & 72 & 12 & Main & Peripheral \\
\hline Tif & Terrestrial insect fragments & 71 & 21 & Main & Peripheral \\
\hline $\mathrm{Ch}$ & Chironomidae & 46 & 75 & Peripheral & Main \\
\hline$V f$ & Vegetable fragments & 32 & 13 & Peripheral & Peripheral \\
\hline $\mathrm{Bi}$ & Bivalvia & 29 & 62 & Peripheral & Main \\
\hline $\mathrm{Hy}$ & Hymenoptera & 27 & 11 & Peripheral & Peripheral \\
\hline Os & Ostracoda & 26 & 38 & Peripheral & Peripheral \\
\hline Aif & Aquatic insect fragments & 22 & 9 & Peripheral & Peripheral \\
\hline $\mathrm{Di}$ & Diptera & 21 & 38 & Peripheral & Peripheral \\
\hline $\operatorname{Tr}$ & Trichoptera & 19 & 23 & Peripheral & Peripheral \\
\hline $\mathrm{Se}$ & Seeds & 10 & 6 & Peripheral & Peripheral \\
\hline $\mathrm{Ce}$ & Ceratopogonidae & 6 & 7 & Peripheral & Peripheral \\
\hline $\mathrm{Te}$ & Tecameba & 6 & 11 & Peripheral & Peripheral \\
\hline Co & Coleoptera & 5 & 6 & Peripheral & Peripheral \\
\hline $\mathrm{Ga}$ & Gastropoda & 4 & 8 & Peripheral & Peripheral \\
\hline Ep & Ephemeroptera & 4 & 2 & Peripheral & Peripheral \\
\hline
\end{tabular}


Table 3. Continued...

\begin{tabular}{|c|c|c|c|c|c|}
\hline \multirow{2}{*}{ Code } & \multirow{2}{*}{ Food items } & \multicolumn{2}{|c|}{ Number of Interactions } & \multicolumn{2}{|c|}{$\begin{array}{c}\text { Classification of } \\
\text { principal-peripheral core }\end{array}$} \\
\hline & & RS & NC & RS & NC \\
\hline $\mathrm{Sa}$ & Sand & 4 & 6 & Peripheral & Peripheral \\
\hline Cha & Chaoboridae & 3 & 20 & Peripheral & Peripheral \\
\hline $\mathrm{Sc}$ & Scales & 3 & 13 & Peripheral & Peripheral \\
\hline Od & Odonata & 2 & 7 & Peripheral & Peripheral \\
\hline $\mathrm{Cl}$ & Cladocera & 1 & 6 & Peripheral & Peripheral \\
\hline $\mathrm{Ar}$ & Araneae & - & 1 & - & Peripheral \\
\hline $\mathrm{Ra}$ & Residual ration & - & 60 & - & Main \\
\hline
\end{tabular}

as omnivorous (the current study), herbivorous and even as piscivorous (Braga, 1990; Hahn et al., 1998; Luiz et al., 1998). Schizodon nasutus and I. labrosus also consumed residual ration, although at lower amounts. It seemed like "accidental consumption" since detritus was the main item observed for both species. However, it did not apply to S. insculpta, which had detritus as the main food item and did not show evidence of residual ration. However, $S$. insculpta consumed small particles mixed to detritus, and it hindered the proper identification of its stomach contents.

Changes in food availability from allochthonous resources, such as residual ration, can affect populations at all trophic network levels (Ramos et al., 2013). Our outputs revealed that fish species can almost exclusively feed on residual ration, as observed for $A$. lacustris (87.3\%) around in fish farming (NC), whereas terrestrial insect fragments were the main food item in the diet of this species in the RS site. Ramos et al. (2013) have investigated A. lacustris feeding on diet composed of insect fragments; they observed this very same pattern and vegetable fragments in natural environment. Astyanax lacustris is considered omnivorous (Pereira et al., 2016) and its high ration intake can indicate the likely ability to buffer the ration input into the environment as biofilter, as observed in other studies (Felsing et al., 2005; Ramos et al., 2008; Xia et al., 2016). However, it is worth emphasizing that this condition should not be used as isolated solution to control artificial feed import. The addition of trophic changes in the system have led to other negative effects such as reduced richness and diversity of wild ichthyofauna in these changed environments (Nobile et al., 2018).

According to Barrett et al. (2019), the effects of cage fish on fish abundance and diversity are likely dependent on the assessed functional group; most surveys conducted with fish populations at fishing farms and reference sites often target mobile generalist carnivores. The input of allochthonous food resources can favor opportunistic and generalist species belonging to the local ichthyofauna by exploiting the new resource available in the environment.

This outcome was also observed through the greater network connectance in NC. Although the authors claim that node addition to the network tends to decrease connectance (Yodzis, 1980), the potential to use residual ration deriving from cage fish farming in the current study has shown that the network presenting the largest number of nodes was also the most connected one. The strategy of using the new food available in the environment was also observed for Apareiodon affinis (Steindachner, 1879) and Pimelodus maculatus Lacepede, 1803 in this very same artificial Neotropical reservoir (Brandão et al., 2012, 2014).

It is worth mentioning that resource composition patterns observed in the ecosystem differ among aquatic habitats, as well as that the environmental conditions in the local habitat can significantly affect resource availability in trophic networks (Doi, 2009). Thus, it is necessary enabling the permanent monitoring of environments subjected to strong human influence, such as large artificial reservoirs.

Although both interaction networks presented nested pattern and virtually the same food items, the rank of items in the bipartite graph varied between sites. This difference may have been caused by the presence of residual ration in NC and by variations in food availability. Since nutrient availability was not assessed in these sites, it was not possible getting to a more accurate conclusion about variations in the rank of food items available in the networks. However, the current findings have shown that the presence of residual ration has influenced the fish-food item interaction and, consequently, the food chain in this ecosystem when the investigated fish incorporated ration to the network. 
According to Dunne et al. (2002), changes in food chain structure mediate the effects of biodiversity loss, such as secondary and cascading extinctions. The aforementioned authors also argue that these extinctions affect ecosystems in different ways, depending on the trophic functions of the removed species.

Studies about ecological networks have shed light on how complex nature can persist and on how it affects ecosystem functioning (Winemiller, 1990; Woodward \& Hildrew, 2002; Woodward, 2009; Ings et al., 2009). It is essential understanding these aspects in order to predict and potentially mitigate the consequences of increasing environmental disturbances, such as habitat loss, climate change and invasion by non-native species (Ings et al., 2009).

Results have confirmed the hypothesis of the current study. They have shown that the fish fauna, which changed the trophic network of local fish-food interactions, used residual ration deriving from fish farms. Thus, these results can contribute to the elaboration of management plans and to the development of policies focused on the conservation and preservation of continental ecosystems.

\section{Acknowledgements}

The authors would like to thank Fundação de Amparo à Pesquisa do Estado de São Paulo (FAPESP processes 2007/58246-4 and 2008/52139-4), for the scholarship granted to the first author and for the auxiliary financial resources (FAPESP process number 07/58246-4). The authors are also grateful to Coordenação de Aperfeiçoamento de Pessoal de Nível Superior (CAPES), for the financial and scientific support (Finance Code 001). I.P.R. is supported by Conselho Nacional de Desenvolvimento Científico e Tecnológico (CNPq) (process 303311/2018-5). We also thank the team of Laboratório de Biologia e Ecologia de Peixes (LABECO), Instituto de Biociências de Botucatu and the Universidade Estadual Paulista (UNESP), for providing the infrastructure to conduct this study.

\section{References}

ALMEIDA-NETO, M., GUIMARÃES, P., GUIMARÃES JÚNIOR, P.R., LOYOLA, R.D. and ULRICH, W. A consistent metric for nestedness analysis in ecological systems: reconciling concept and measurement. Oikos, 2008, 117(8), 1227-1239. http://dx.doi.org/10.1111/j.00301299.2008.16644.x.
ANDERSON, M.J. A new method for non-parametric multivariate analysis of variance. Austral Ecology, 2001, 26, 32-46.

BARRETT, L.T., SWEARER, S.E. and DEMPSTER, T., 2019. Impacts of marine and freshwater aquaculture on wildlife: a global meta冈analysis. Reviews in Aquaculture, vol. 11, no. 4, pp. 1022-1044. http://dx.doi.org/10.1111/raq.12277.

BARTOZEK, E.C.R., BUENO, N.C. and RODRIGUES, L.C. Influence of fish farming in net cages on phytoplankton structure: a case study in a subtropical Brazilian reservoir. Brazilian Journal of Biology = Revista Brasileira de Biologia, 2014, 74(1), 145-155. http://dx.doi.org/10.1590/15196984.21912. PMid:25055096.

BASCOMPTE, J., JORDANO, P., MELIÁN, C.J. and OLESEN, J.M. The nested assembly of plantanimal mutualistic networks. Proceedings of the National Academy of Sciences of the United States of America, 2003, 100(16), 9383-9387. http://dx.doi. org/10.1073/pnas.1633576100. PMid:12881488.

BATAGELJ, V. and MRVAR, A. Pajek-program for large network analysis. Connections, 1998, 21, 47-57.

BICUDO, C.E.M. and BICUDO, R.M.T. Algas de águas continentais brasileiras chave ilustrada para identificação de gêneros. São Paulo: Fundação Brasileira para o Desenvolvimento do Ensino de Ciências, 1970.

BRAGA, F.M.S. Aspectos da reprodução e alimentação de peixes comuns em um trecho do rio Tocantins entre Imperatriz e Estreito, Estados do Maranhão e Tocantins, Brasil. Revista Brasileira de Biologia, 1990, 50, 547-558.

BRANDÃO, H., LOBÓN-CERVIÁ, J., RAMOS, I.P., SOUTO, A.C., NOBILE, A.B., ZICA, E.O.P. and CARVALHO, E.D. Influence of a cage farming on the population of the fish species Apareiodon affinis (Steindachner, 1879) in the Chavantes reservoir, Paranapanema River SP/PR, Brazil. Acta Limnologica Brasiliensia, 2012, 24(4), 438-448. http://dx.doi. org/10.1590/S2179-975X2013005000012.

BRANDÃO, H., NOBILE, A.B., SOUTO, A.C., RAMOS, I.P., SOUSA, J.Q. and CARVALHO, E.D. Influence of cage fish farming on the diet and biological attributes of Galeocharax knerii in the Chavantes Reservoir, Brazil. Boletim do Instituto de Pesca, 2013, 39, 157-167.

BRANDÃO, H., SANTANA, J.C.O., RAMOS, I.P. and CARVALHO, E.D. Influence of cage farming on feeding and reproductive aspects of Pimelodus maculatus Lacépède, 1803 (Siluriformes: Pimelodidae) in the Chavantes Reservoir, Brazil. Acta Scientiarum. Biological Sciences, 2014, 36(1), 41-50. http://dx.doi.org/10.4025/actascibiolsci. v36i1.21039. 
BRANDÃO, H., VIDOTTO-MAGNONI, A.P., RAMOS, I.P. and CARVALHO, E.D. Assessment of the ichthyofauna in stretches under the influence of Salto Grande Reservoir (Middle Paranapanema River, SP/PR, Brazil). Acta Limnologica Brasiliensia, 2009, 21, 451-463.

BUCKUP, P.A., MENEZES, N.A. and GHAZZI, S.M. Catálogo das espécies de peixes de água doce do Brasil. 1. ed. Rio de Janeiro: Museu Nacional, 2007.

CARVALHO, E.D., SILVA, R.J., RAMOS, I.P., PAES, J.V.K., ZANATTA, A.S., BRANDÃO, H., ZICA, E.O.P., NOBILE, A.B., ACOSTA, A.A. and DAVID, G.S. Ecological features of large neotropical reservoirs and its relation to health of cage reared fish. In: E.D. CARVALHO, G.M. DAVID and R.J. SILVA, eds. Health and environment in aquaculture. Rijeka: Intech, 2012, pp. 361-382.

CLARKE, K.R. Non-parametric multivariate analysis of changes in community structure. Australian Journal of Ecology, 1993, 18(1), 117-143. http://dx.doi. org/10.1111/j.1442-9993.1993.tb00438.x.

CYRINO, J.E.P., BICUDO, Á.J.A., SADO, R.Y., BORGHESI, R. and DAIRIK, J.K. Fish farming and the environment - the use of environmental friendly feeds in fish culture. Revista Brasileira de Zootecnia, 2010, 39, 68-87. http://dx.doi.org/10.1590/S151635982010001300009 .

DÁTTILO, W., GUIMARÃES JÚNIOR, P.R. and IZZO, T.J. Spatial structure of ant-plant mutualistic networks. Oikos, 2013, 122(11), 1643-1648. http:// dx.doi.org/10.1111/j.1600-0706.2013.00562.x.

DAVID, G.S., CARVALHO, E.D., LEMOS, D., SILVEIRA, A.N. and DALL'AGLIO-SOBRINHO, M. Ecological carrying capacity for intensive tilapia (Oreochromis niloticus) cage aquaculture in a large hydroelectrical reservoir in Southeastern Brazil. Aquacultural Engineering, 2015, 66, 30-40. http:// dx.doi.org/10.1016/j.aquaeng.2015.02.003.

DEMÉTRIO, J.A., GOMES, L.C., LATINI, J.D. and AGOSTINHO, A.A. Influence of net cage farming on the diet of associated wild fish in a Neotropical reservoir. Aquaculture, 2012, 330, 172-178. http:// dx.doi.org/10.1016/j.aquaculture.2011.11.026.

DOI, H. Spatial patterns of autochthonous and allochthonous resources in aquatic food webs. Population Ecology, 2009, 51(1), 57-64. http://dx.doi. org/10.1007/s10144-008-0127-z.

DORMANN, C.F., FRÜND, J., BLÜTHGEN, N. and GRUBER, B. Indices, graphs and null models: analyzing bipartite ecological networks. The Open Ecology Journal, 2009, 2(1), 7-24. http://dx.doi.org /10.2174/1874213000902010007.

DUKE ENERGY. Peixes do rio Paranapanema. São Paulo: Horizonte Geográfico, 2008.

DUNNE, J.A., WILLIAMS, R.J. and MARTINEZ, N.D. Network structure and biodiversity loss in food webs: robustness increases with connectance. Ecology Letters, 2002, 5(4), 558-567. http://dx.doi. org/10.1046/j.1461-0248.2002.00354.x.

FELSING, M., GLENCROSS, B. and TELFER, T. Preliminary study on the effects of exclusion of wild fauna from aquaculture cages in a shallow marine environment. Aquaculture, 2005, 243(14), 159-174. http://dx.doi.org/10.1016/j. aquaculture.2004.09.033.

GRAÇA, W.J. and PAVANELLI, C.S. Peixes da planicie de inundação do alto rio Paraná e áreas adjacentes. Maringá: Eduem, 2007.

GUIMARÃES JÚNIOR, P.R. and GUIMARÃES, P. Improving the analyses of nestedness for large sets of matrices. Environmental Modelling \& Software, 2006, 21(10), 1512-1513. http://dx.doi.org/10.1016/j. envsoft.2006.04.002.

HAHN, N.S., AGOSTINHO, A.A., GOMES, L.C. and BINI, L.M. Estrutura trófica da ictiofauna do reservatório de Itaipu (Paraná-Brasil) nos primeiros anos de sua formação. Interciencia, 1998, 23, 299305.

HAKANSON, L. Changes to lake ecosystem structure resulting from fish cage farm emissions. Lakes and Reservoirs: Research and Management, 2005, 10(1), 71-80. http://dx.doi.org/10.1111/j.14401770.2005.00253.x.

HEDBERG, N., KAUTSKY, N., HELLSTRÖM, M. and TEDENGREN, M. Spatial correlation and potential conflicts between sea cage farms and coral reefs in South East Asia. Aquaculture, 2015, 448, 418-426. http://dx.doi.org/10.1016/j. aquaculture.2015.06.024.

HYSLOP, E.J. Stomach contents analysis: a review of methods and their application. Journal of Fish Biology, 1980, 17(4), 411-429. http://dx.doi. org/10.1111/j.1095-8649.1980.tb02775.x.

INGS, T.C., MONTOYA, J.M., BASCOMPTE, J., BLÜTHGEN, N., BROWN, L., DORMANN, C.F., EDWARDS, F., FIGUEROA, D., JACOB, U., JONES, J.I., LAURIDSEN, R.B., LEDGER, M.E., LEWIS, H.M., OLESEN, J.M., VAN VEEN, F.J.F., WARREN, P.H. and WOODWARD, G. Review: ecological networks - beyond food webs. Journal of Animal Ecology, 2009, 78(1), 253-269. http:// dx.doi.org/10.1111/j.1365-2656.2008.01460.x. PMid:19120606.

JORDANO, P. Patterns of mutualistic interactions in pollination and seed dispersal: connectance, dependence asymmetries, and coevolution. American Naturalist, 1987, 129(5), 657-677. http://dx.doi. org/10.1086/284665.

KLIEMANN, B.C.K., DELARIVA, R.L., AMORIM, J.P.A., RIBEIRO, C.S., SILVA, B., SILVEIRA, R.V. and RAMOS, I.P. Dietary changes and histophysiological responses of a wild fish (Geophagus 
cf. proximus) under the influence of tilapia cage farm. Fisheries Research, 2018, 204, 337-347. http://dx.doi. org/10.1016/j.fishres.2018.03.011.

LANGE, D., DÁTTILO, W. and DEL-CLARO, K. Influence of extrafloral nectary phenology on antplant mutualistic networks in a Neotropical Savanna. Ecological Entomology, 2013, 38(5), 463-469. http:// dx.doi.org/10.1111/een.12036.

LIMA, L.B., OLIVEIRA, F.J.M., GIACOMINI, H.C. and LIMA-JUNIOR, D.P. Expansion of aquaculture parks and the increasing risk of non-native species invasions in Brazil. Reviews in Aquaculture, 2018, 10(1), 111-122. http://dx.doi. org/10.1111/raq.12150.

LUIZ, E.A., AGOSTINHO, A.A., GOMES, L.C. and HAHN, N.S. Ecologia trófica de peixes em riachos da bacia do rio Paraná. Revista Brasileira de Biologia, 1998, 58, 273-285.

MONTALTO, A., MARTINEZ, M., RINALDI, A., SARA, G. and MIRTO, S. The effect of the quality of diet on the functional response of Mytilus galloprovincialis (Lamarck, 1819): implications for integrated multitrophic aquaculture (IMTA) and marine spatial planning. Aquaculture, 2017, 468, 371-377. http://dx.doi.org/10.1016/j. aquaculture.2016.10.030.

MUGNAI, R., NESSIMIAN, J.L. and BAPTISTA, D.F. Manual de identificação de macroinvertebrados aquáticos do Estado do Rio de Janeiro. Rio de Janeiro: Technical Boocks, 2010.

NABIRYE, H., MWEBAZA-NDAWULA, L., BUGENYI, F.W.B. and MUYODI, F.J. The evaluation of cage fish farming effects on water quality using selected benthic macro-invertebrate community parameters in the Napoleon gulf, Northern Lake Victoria. International Journal of Fisheries and Aquatic Studies, 2016, 4, 42-50.

NING, Z., LIU, S., ZHANG, G., NING, X., LI, R., JIANG, Z., FANG, J. and ZHANG, J. Impacts of an integrated multi-trophic aquaculture system on benthic nutrient fluxes: a case study in Sanggou Bay, China. Aquaculture Environment Interactions, 2016, 8, 221-232. http://dx.doi.org/10.3354/aei00144.

NOBILE, A.B. A ictiofauna agregada a um sistema de piscicultura em tanques-rede na represa oligotrófica de Chavantes (médio rio Paranapanema, SPI $P R$ ): composição de espécies e atributos ecológicos [Dissertação de Mestrado em Ciências Biológicas (Zoologia)]. Botucatu: Universidade Estadual Paulista, 2010. [viewed 15 July 2021]. Available from: https://repositorio.unesp.br/bitstream/ handle/11449/99413/nobile_ab_me_botib. pdf?sequence $=1$

NOBILE, A.B., CUNICO, A.M., VITULE, J.R.S., QUEIROZ, J., VIDOTTO-MAGNONI, A.P., GARCIA, D.A.Z., ORSI, M.L., LIMA, F.P., ACOSTA, A.A., SILVA, R.J., PRADO,
F.D., PORTO-FORESTI, F., BRANDÁO, H., FORESTI, F., OLIVEIRA, C. and RAMOS, I.P. Status and recommendations for sustainable freshwater aquaculture in Brazil, 2019. Reviews in Aquaculture, 2020, 12, 1495-1517.

NOBILE, A.B., ZANATTA, A.S., BRANDÃO, H., ZICA, E.O., LIMA, F.P., FREITAS-SOUZA, D., CARVALHO, E.D., SILVA, R.J. and RAMOS, I.P. Cage fish farm act as a source of changes in the fish community of a Neotropical reservoir. Aquaculture, 2018, 495, 780-785. http://dx.doi.org/10.1016/j. aquaculture.2018.06.053.

OTA, R.R., DEPRÁ, G.C., GRAÇA, W.J. and PAVANELLI, C.S. Peixes da planície de inundação do alto rio Paraná e áreas adjacentes: revised, annotated and updated. Neotropical Ichthyology, 2018, 16(2), e170094. http://dx.doi.org/10.1590/1982-022420170094.

PEREIRA, L.S., AGOSTINHO, A.A. and DELARIVA, R.L. Effects of river damming in Neotropical piscivorous and omnivorous fish: feeding, body condition and abundances. Neotropical Ichthyology, 2016, 14(1), 1-12. http://dx.doi.org/10.1590/19820224-20150044.

PRICE, K.D., BLACK, B.T., HARGRAVE, J.A. and MORRIS JUNIOR, J.A. Morris Marine cage culture and the environment: effects on water quality and primary production. Aquaculture Environment Interactions, 2015, 6(2), 151-174. http://dx.doi. org/10.3354/aei00122.

RAMOS, I.P., BRANDÁO, H., ZANATTA, A.S., ZICA, E.O.P., SILVA, R.J., REZENDE-AYROZA, D.M.M. and CARVALHO, E.D. Interference of cage fish farm on diet, condition factor and numeric abundance on wildfish in a Neotropical reservoir. Aquaculture, 2013, 414, 56-62. http://dx.doi. org/10.1016/j.aquaculture.2013.07.013.

RAMOS, I.P., VIDOTTO-MAGNONI, A.P. and CARVALHO, E.D. Influence of cage fish farming on the diet of dominant fish species of a Brazilian reservoir (Tietê River, High Paraná River basin). Acta Limnologica Brasiliensia, 2008, 20, 245-252.

TOMASSETTI, P., GENNARO, P., LATTANZI, L., MERCATAli, I., PERSiA, E., VANi, D. and PORRELlO, S. Benthic community response to sediment organic enrichment by Mediterranean fish farms: Case studies. Aquaculture, 2016, 450, 262-272. http://dx.doi.org/10.1016/j. aquaculture.2015.07.019.

VÉLEZ, E.J., LUTFI, E., AZIZI, S.H., PERELLÓ, M., SALMERÓN, C., RIERA-CODINA, M., IBARZ, A., FERNÁNDEZ-BORRÀS, J., BLASCO, J., CAPILLA, E., NAVARRO, I. and GUTIÉRREZ, J. Understanding fish muscle growth regulation to optimize aquaculture production. Aquaculture, 2017, 467, 28-40. http://dx.doi.org/10.1016/j. aquaculture.2016.07.004. 
WINEMILLER, K.O. Spatial and temporal variation in tropical fish trophic networks. Ecological Monographs, 1990, 60(3), 331-367. http://dx.doi. org/10.2307/1943061.

WOODWARD, G. and HILDREW, A.G. Food web structure in riverine landscapes. Freshwater Biology, 2002, 47(4), 777-798. http://dx.doi.org/10.1046/ j.1365-2427.2002.00908.x.

WOODWARD, G. Biodiversity, ecosystem functioning and food webs in fresh waters: assembling the jigsaw puzzle. Freshwater Biology, 2009, 54(10), 2171-2187. http://dx.doi.org/10.1111/j.13652427.2008.02081.x.

XIA, B., SUN, Z., GAO, Q., DONG, S. and WANG, F. Carbon, nitrogen and phosphorus budgets of silver carp Hypophthalmichthys molitrix with the co-culture of grass carp Ctenopharyngodon idella. Aquaculture
Environment Interactions, 2016, 8, 453-461. http:// dx.doi.org/10.3354/aei00191.

YODZIS, P. The connectance of real ecosystems. Nature, 1980, 284(5756), 544-545. http://dx.doi. org/10.1038/284544a0.

ZANIBONI-FILHO, E., PEDRON, J.S. and RIBOLLI, J. Opportunities and challenges for fish culture in Brazilian reservoirs: a review. Acta Limnologica Brasiliensia, 2018, 30(0), 30. http:// dx.doi.org/10.1590/s2179-975x12617.

Received: 07 September 2019 Accepted: 01 July 2021

Associate Editors: Ronaldo Angelini 